In cooperation with the U.S. Army

\title{
Geologic Framework and Hydrogeologic Features of the Glen Rose Limestone, Camp Bullis Training Site, Bexar County, Texas
}

Water-Resources Investigations Report 03-4081

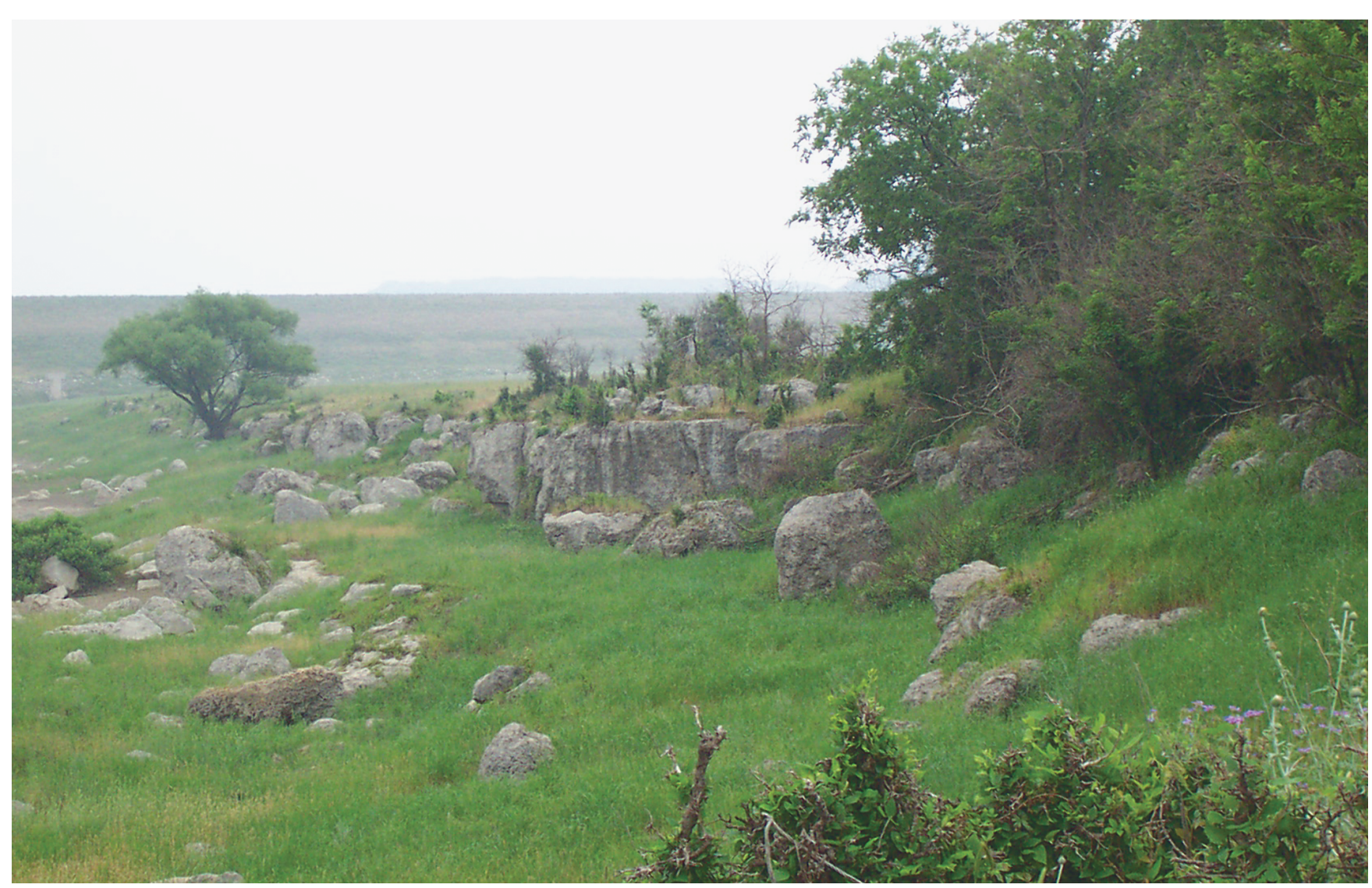

U.S. Department of the Interior U.S. Geological Survey 


\section{Cover:}

Looking south along Salado Creek at Camp Bullis Training site. The outcropping rocks compose a biostrome in the upper Glen Rose Limestone. 
U.S. Department of the Interior

U.S. Geological Survey

\section{Geologic Framework and Hydrogeologic Features of the Glen Rose Limestone, Camp Bullis Training Site, Bexar County, Texas}

By Allan K. Clark

U.S. GEOLOGICAL SURVEY

Water-Resources Investigations Report 03-4081

In cooperation with the U.S. Army

Austin, Texas

2003 


\section{U.S. DEPARTMENT OF THE INTERIOR}

Gale A. Norton, Secretary

\section{U.S. GEOLOGICAL SURVEY}

Charles G. Groat, Director

Any use of trade, product, or firm names is for descriptive purposes only and does not imply endorsement by the U.S. Government.

For additional information write to

\section{District Chief}

U.S. Geological Survey

8027 Exchange Dr.

Austin, TX 78754-4733

E-mail: dc_tx@usgs.gov

Copies of this report can be purchased from

U.S. Geological Survey

Information Services

Box 25286

Denver, CO 80225-0286

E-mail: infoservices@usgs.gov 


\section{CONTENTS}

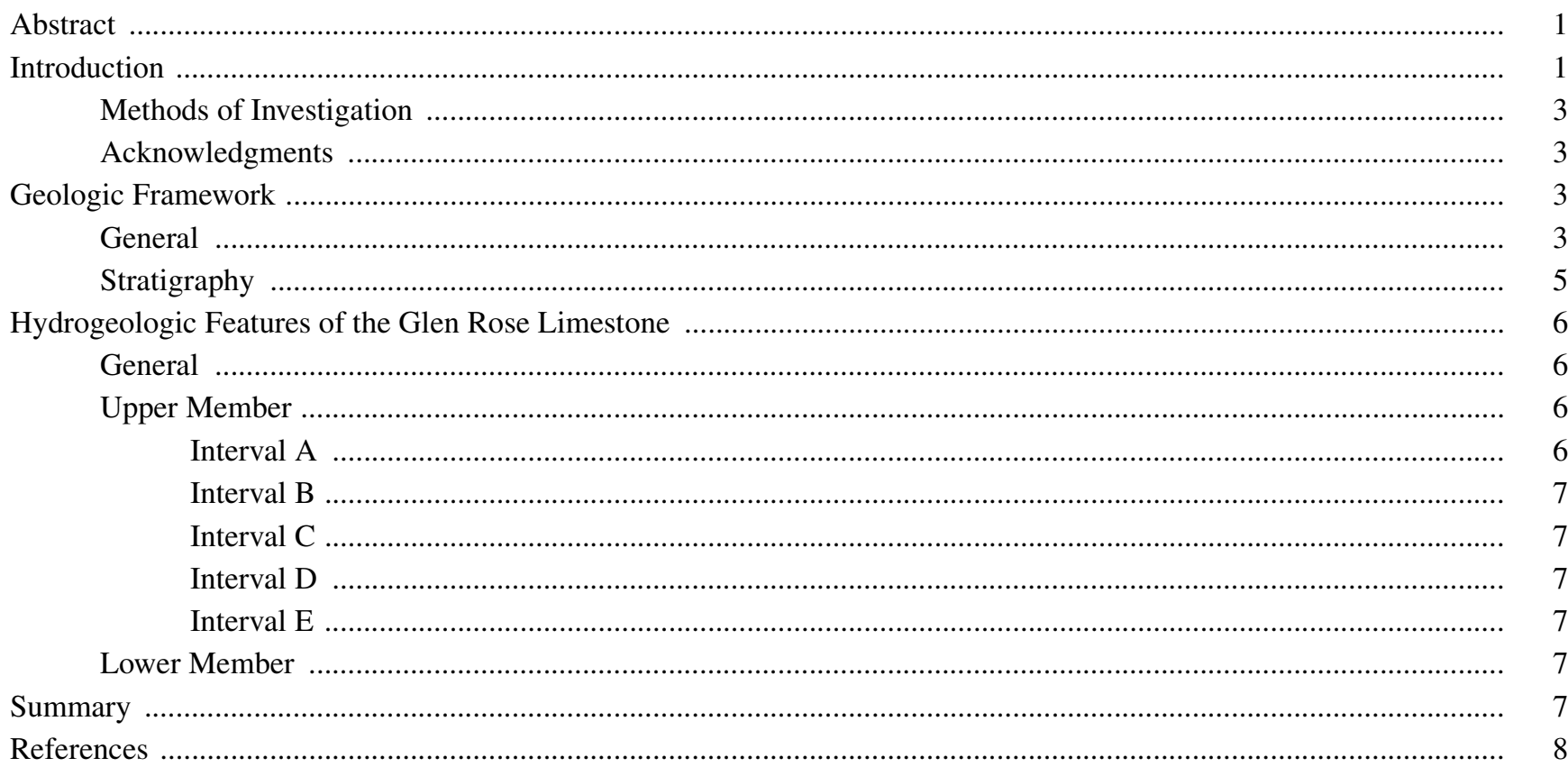

\section{PLATE}

(Plate is in pocket)

1. Map showing hydrogeologic subdivisions of the Edwards and Trinity aquifers that crop out; and generalized stratigraphic section, Camp Bullis Training Site, Bexar County, Texas

\section{FIGURE}

1. Map showing location of Camp Bullis Training Site, Bexar County, Texas

\section{TABLE}

1. Summary of the lithologic and hydrogeologic properties of the hydrogeologic subdivisions of the Glen Rose Limestone and associated units that crop out, Camp Bullis Training Site, Bexar County, Texas

\section{VERTICAL DATUM}

Vertical coordinate information is referenced to the National Geodetic Vertical Datum of 1929 (NGVD 29). 


\title{
Geologic Framework and Hydrogeologic Features of the Glen Rose Limestone, Camp Bullis Training Site, Bexar County, Texas
}

\author{
By Allan K. Clark
}

\begin{abstract}
The Glen Rose Limestone crops out over most of the Camp Bullis Training Site in northern Bexar County, Texas, where it consists of upper and lower members and composes the upper zone and the upper part of the middle zone of the Trinity aquifer. Uncharacteristically permeable in northern Bexar County, the Glen Rose Limestone can provide avenues for recharge to and potential contamination of the downgradient Edwards aquifer, which occupies the southeastern corner of Camp Bullis.
\end{abstract}

The upper member of the Glen Rose Limestone characteristically is thin-bedded and composed mostly of soft limestone and marl, and the lower Glen Rose typically is composed mostly of relatively massive, fossiliferous limestone. The upper member, about 410 to 450 feet thick at Camp Bullis, was divided in this study into five hydrogeologic subdivisions, A through $\mathrm{E}$ (youngest to oldest).

The approximately 120 -foot-thick Interval A has an abundance of caves, which is indicative of its generally well developed fracture, channel, and cavern porosity that in places provides appreciable permeability. The 120 - to 150 -foot-thick Interval B is similar to Interval A but with less cave development and considerably less permeability. The 10- to 20-foot-thick Interval C, a layer of partly to mostly dissolved soluble carbonate minerals, is characterized by breccia porosity, boxwork permeability, and collapse structures that typically divert ground water laterally to discharge at land surface. The 135- to 180-foot-thick Interval D generally has low porosity and little permeability with some local exceptions, most notably the caprinid biostrome just below the top of the interval, which appears to be permeable by virtue of excellent moldic, vug, fracture, and cavern porosity. The 10- to 20-footthick Interval E, a layer of partly to mostly dissolved evaporites similar to Interval C, has similar hydrogeologic properties and a tendency to divert ground water laterally.

\section{INTRODUCTION}

The Edwards aquifer is critically important to south-central Texas. In the San Antonio area of Bexar County, the Edwards aquifer supplies water for more than 1.4 million people (U.S. Census Bureau, 2002) and for almost all agricultural, commercial, and industrial purposes. The Trinity aquifer, adjacent to the Edwards aquifer to the north, is hydraulically connected to the recharge zone (outcrop) of the Edwards aquifer. The upper zone and the upper part of the middle zone of the Trinity aquifer are composed of the Glen Rose Limestone. The Glen Rose Limestone crops out over all but the southeastern corner of the Camp Bullis Training Site, a field training site for military and government agencies in northern Bexar County (fig. 1). The southeastern corner of the site lies within the recharge zone of the Edwards aquifer. Depending on the local porosity and associated permeability, the Glen Rose Limestone can provide avenues for recharge and (potentially) contaminants to enter the downgradient Edwards aquifer.

The U.S. Geological Survey (USGS), in cooperation with the U.S. Army, studied the Glen Rose Limestone at Camp Bullis during 1999-2001 to better understand its porosity and permeability and thus the conditions for recharge to and potential contamination of the Edwards aquifer. Results of recent field work and background information from existing literature are 


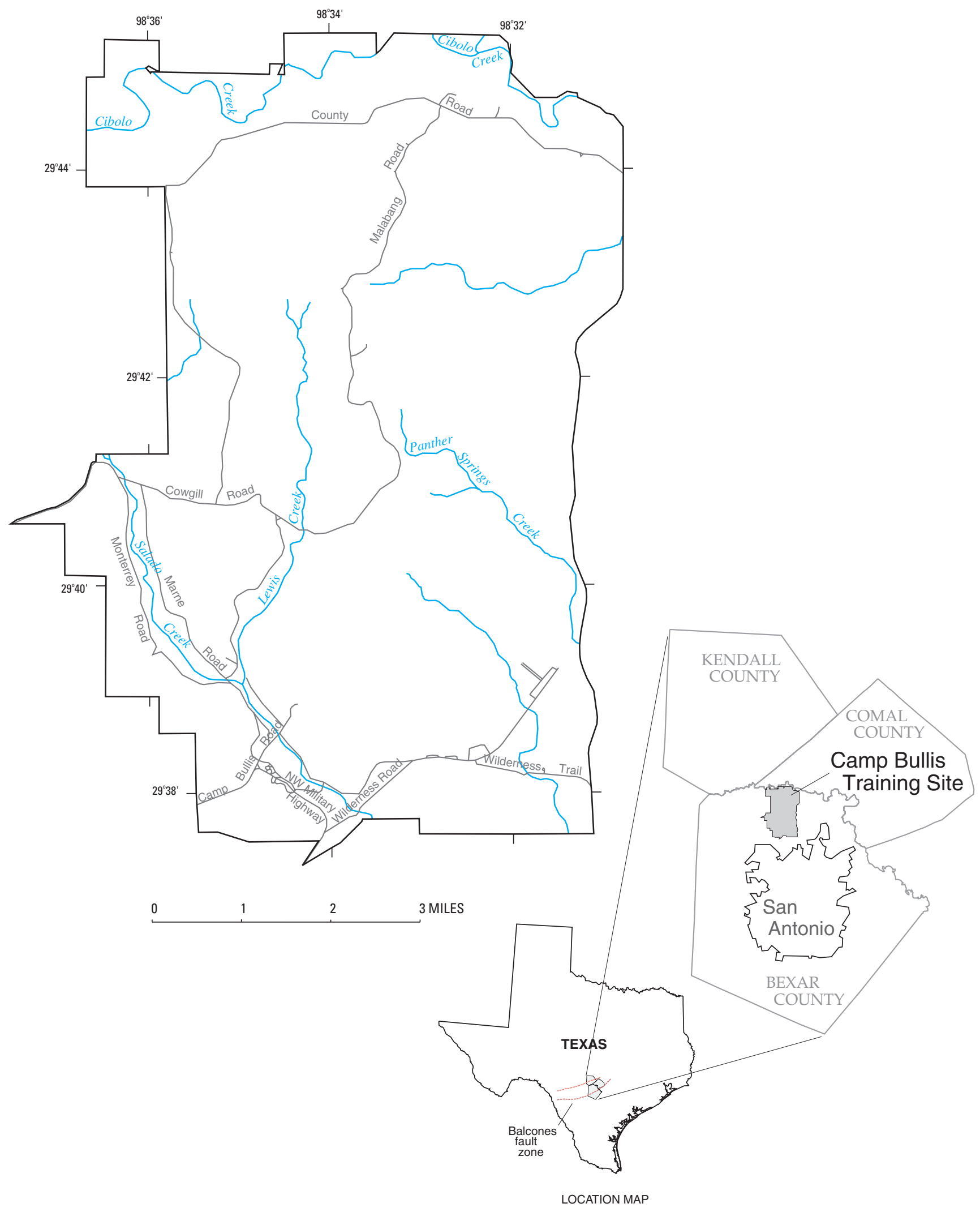

Figure 1. Location of Camp Bullis Training Site, Bexar County, Texas. 
presented in this report to describe the geologic framework and hydrogeologic features of (principally) the outcrop of the Glen Rose Limestone at Camp Bullis. The upper member of the Glen Rose Limestone is divided into five (informal) hydrogeologic subdivisions . An outcrop map, generalized stratigraphic section, and table are provided to summarize the relevant hydrostratigraphic characteristics and hydrogeologic properties.

Because detailed study of the Edwards aquifer outcrop was not within the scope of this project, readers are referred to Stein and Ozuna (1995) for information on the geologic framework and hydrogeologic features of those rocks.

\section{Methods of Investigation}

Geophysical well logs were used in conjunction with aerial photographs and geological data from previous reports to map the Glen Rose Limestone at Camp Bullis. With the aid of a Global Positioning System (GPS), the field mapping was done on 7 1/2-minute USGS topographic maps. Determinations of the hydrogeologic subdivisions and the porosity and permeability were inferred from accessible geologic outcrops. Distinct marker beds, such as the Corbula bed at the base of the upper member of the Glen Rose Limestone, were used where possible to help identify the top and bottom of key hydrogeologic subdivisions. The field data were digitized into a Geographic Informations System (GIS) database. Thicknesses of the mapped units were estimated from well logs in and around Camp Bullis or obtained from previous reports.

The classification systems of Dunham (1962) and Choquette and Pray (1970) were used to describe the carbonate rocks at Camp Bullis. Dunham's (1962) carbonate-rock classifications-determined on the basis of the arrangement and ratio of fine to coarse sediment-include grainstone, packstone, wackestone, and mudstone. The porosity classifications of Choquette and Pray (1970) were used to characterize the porosity type as either fabric selective or not-fabric selective.

Porosity that reflects the depositional or (typically early) diagenetic elements of a sedimentary rock and tends to form along specific lithostratigraphic horizons is termed "fabric selective." Fabric selective porosity includes interparticle, intraparticle, intercrystalline, moldic, and fenestral types. Porosity that results (typically later) from structural or solutional processes within or across lithostratigraphic horizons is termed "not-fabric selective." Not-fabric selective porosity includes vug, channel, fracture, and cavern types. Breccia porosity is a subcategory of interparticle porosity that can be either fabric selective or not-fabric selective. Depending on rock type and conditions over geologic time, both fabric and not-fabric selective porosity can evolve into appreciable permeability.

Aerial photographs were used to aid fault identification. Although some faults were discernible from lithologic and stratigraphic dissimilarities or-in some cases-from well logs, most fault displacements were difficult to identify in the field. Some of the relatively small-displacement faults, however, could be inferred from lineaments indicated in aerial photographs.

\section{Acknowledgments}

The author thanks Dusty Bruns (Camp Bullis Training Site) and Dr. George Veni (George Veni \& Associates) for their valuable assistance in this study. The author also is indebted to the late Joe Ivy, a local cave expert, for his help in the field.

\section{GEOLOGIC FRAMEWORK}

\section{General}

All rocks exposed at the Camp Bullis Training Site (pl. 1; table 1) are of sedimentary origin and Lower Cretaceous age. The formations typically are fossiliferous limestone, characterized by alternating and interfingering beds of packstone, wackestone, mudstone, and marl with interbedded grainstone and partly to mostly dissolved evaporites (gypsum and anhydrite). The age of the rocks generally decreases from north to south. The oldest exposed rocks (on the northern part of the site) compose the (informal) lower member of the Glen Rose Limestone. Although not everywhere evident at Camp Bullis, the Glen Rose Limestone likely dips about 10 to 15 feet per mile to the southeast, which is similar to the reported dip of the Edwards aquifer in Bexar County (Arnow, 1959).

At Camp Bullis, the Edwards aquifer is composed of the Kainer Formation of the Edwards Group. As the result of downfaulting in the southeastern part of Camp Bullis, the Kainer Formation is juxtaposed against the older Glen Rose Limestone on the northwest. Between Cowgill Road (on the northwest) and Wilderness Road (on the southeast), erosional remnants of the Kainer Formation cap some of the higher hills underlain by Glen Rose Limestone. 
Table 1. Summary of the lithologic and hydrogeologic properties of the hydrogeologic subdivisions of the Glen Rose Limestone and associated units that crop out, Camp Bullis Training Site, Bexar County, Texas

[Groups, formations, and members modified from Forgotson (1956), Rose (1972), Ashworth (1983); hydrogeologic subdivisions (aquifers, zones) from Maclay (1995), Barker and Ardis (1996); lithologic terminology modified from Dunham (1962); and porosity type modified from Choquette and Pray (1970). AQ, aquifer; CU, confining unit; * not exposed in the study area]

\begin{tabular}{|c|c|c|c|c|c|c|c|c|c|}
\hline \multicolumn{2}{|c|}{$\begin{array}{l}\text { Group, } \\
\text { formation, } \\
\text { member }\end{array}$} & \multicolumn{2}{|c|}{$\begin{array}{l}\text { Hydro- } \\
\text { geologic } \\
\text { subdivision }\end{array}$} & \multirow{2}{*}{$\begin{array}{l}\begin{array}{c}\text { Hydro- } \\
\text { logic } \\
\text { function }\end{array} \\
\mathrm{AQ}\end{array}$} & \multirow{2}{*}{\begin{tabular}{c|}
$\begin{array}{c}\text { Thickness } \\
\text { (feet) }\end{array}$ \\
$50-60$
\end{tabular}} & \multirow{2}{*}{\begin{tabular}{|c|}
\multicolumn{1}{|c|}{ Lithology } \\
$\begin{array}{l}\text { Highly altered crystal- } \\
\text { line limestone; chalky } \\
\text { mudstone; chert }\end{array}$ \\
\end{tabular}} & \multirow{2}{*}{$\begin{array}{l}\text { Field } \\
\text { identification } \\
\text { Boxwork voids, with } \\
\text { neospar and travertine } \\
\text { frame }\end{array}$} & \multirow{2}{*}{\begin{tabular}{|l}
\multicolumn{1}{c}{$\begin{array}{c}\text { Cavern } \\
\text { development }\end{array}$} \\
$\begin{array}{l}\text { Probably extensive } \\
\text { cave develop- } \\
\text { ment }\end{array}$
\end{tabular}} & \multirow{2}{*}{$\begin{array}{c}\text { Porosity type/ } \\
\text { permeability }\end{array}$} \\
\hline \multirow{3}{*}{ 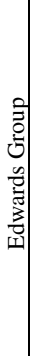 } & $\begin{array}{c}\text { Kirschberg } \\
\text { evaporite } \\
\text { member }\end{array}$ & \multirow{3}{*}{ 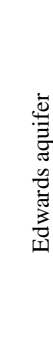 } & $\mathrm{VI}^{1}$ & & & & & & \\
\hline & $\begin{array}{r}\text { Dolomitic } \\
\text { member }\end{array}$ & & $\mathrm{VII}^{1}$ & AQ & $110-130$ & $\begin{array}{l}\text { Mudstone to grain- } \\
\text { stone; crystalline } \\
\text { limestone; chert }\end{array}$ & $\begin{array}{l}\text { Massively bedded, light } \\
\text { gray; Toucasia abundant }\end{array}$ & $\begin{array}{l}\text { Caves related to } \\
\text { structure or } \\
\text { bedding planes }\end{array}$ & $\begin{array}{l}\text { Mostly not-fabric selective; } \\
\text { some bedding plane fabric } \\
\text { selective/water yielding }\end{array}$ \\
\hline & $\begin{array}{l}\text { Basal } \\
\text { nodular } \\
\text { member }\end{array}$ & & $\mathrm{VIII}^{1}$ & $\begin{array}{l}\text { AQ karst; } \\
\text { CU not karst }\end{array}$ & $50-60$ & $\begin{array}{l}\text { Shaly, nodular lime- } \\
\text { stone; mudstone and } \\
\text { miliolid grainstone }\end{array}$ & $\begin{array}{l}\text { Massive, nodular, and } \\
\text { mottled; Exogyra texana }\end{array}$ & $\begin{array}{l}\text { Large lateral caves } \\
\text { at surface; a few } \\
\text { caves near } \\
\text { Cibolo Creek }\end{array}$ & $\begin{array}{l}\text { Fabric selective; stratigraph- } \\
\text { ically controlled/large conduit } \\
\text { flow at surface; no permea- } \\
\text { bility in subsurface }\end{array}$ \\
\hline \multirow{6}{*}{ 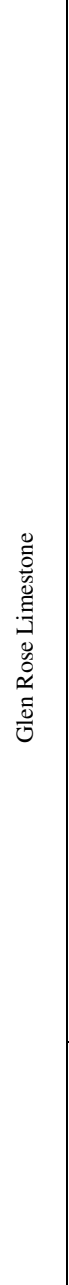 } & \multirow{5}{*}{ 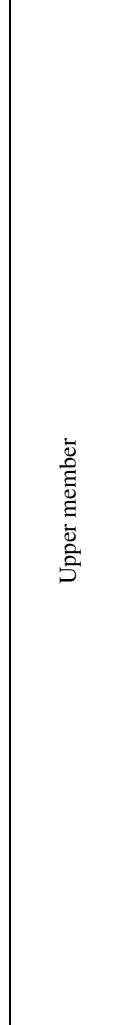 } & \multirow{5}{*}{ 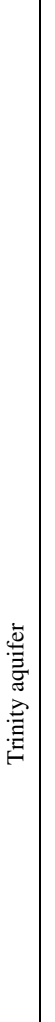 } & $\begin{array}{c}\text { Interval } \\
\mathrm{A}\end{array}$ & $\begin{array}{l}\text { AQ associated } \\
\text { with fractures } \\
\text { and karst; } \\
\text { CU if not }\end{array}$ & $120+$ & $\begin{array}{l}\text { Alternating and inter- } \\
\text { fingering medium- } \\
\text { bedded mudstone, } \\
\text { wackestone, and } \\
\text { packstone with } \\
\text { evaporites locally }\end{array}$ & $\begin{array}{l}\text { Directly underlies } \\
\text { Edwards Group; stair- } \\
\text { step topography; fossils } \\
\text { rare; evaporite beds } \\
\text { locally }\end{array}$ & $\begin{array}{l}\text { Some caves below } \\
\text { contact with } \\
\text { Edwards Group; } \\
\text { caves associated } \\
\text { with fractures } \\
\text { and bedding } \\
\text { planes }\end{array}$ & $\begin{array}{l}\text { Not-fabric selective fracture and } \\
\text { cavern porosity; permeability } \\
\text { near contact with Edwards } \\
\text { Group decreases with depth; } \\
\text { breccia porosity associated } \\
\text { with collapse resulting from } \\
\text { dissolution of evaporite beds }\end{array}$ \\
\hline & & & $\begin{array}{c}\text { Interval } \\
\mathrm{B}\end{array}$ & $\begin{array}{l}\text { CU; } \\
\text { AQ associated } \\
\text { with fractures } \\
\text { and karst }\end{array}$ & $120-150$ & $\begin{array}{l}\text { Alternating and inter- } \\
\text { fingering mudstones, } \\
\text { marls, wackestone, } \\
\text { and packstones }\end{array}$ & $\begin{array}{l}\text { Fossils rare; stair-step } \\
\text { topography }\end{array}$ & Few caves & $\begin{array}{l}\text { Fabric selective interparticle } \\
\text { porosity and not-fabric } \\
\text { selective fracture and some } \\
\text { cavernous porosity; generally } \\
\text { little permeability away from } \\
\text { caves and solutionally } \\
\text { enlarged fractures }\end{array}$ \\
\hline & & & Inteval & AQ & $10-20$ & $\begin{array}{l}\text { Yellow-to-white } \\
\text { calcareous mud and } \\
\text { vuggy mudstone }\end{array}$ & $\begin{array}{l}\text { Yellow calcareous mud, } \\
\text { with springs and seeps; } \\
\text { topography tends to be } \\
\text { flat }\end{array}$ & No known caves & $\begin{array}{l}\text { Fabric selective vug and moldic } \\
\text { porosity with boxwork } \\
\text { permeability }\end{array}$ \\
\hline & & & $\begin{array}{c}\text { Interval } \\
\mathrm{D}\end{array}$ & $\begin{array}{l}\text { AQ associated } \\
\text { with bioherms; } \\
\text { CU above and } \\
\text { below bio- } \\
\text { herms }\end{array}$ & $135-180$ & $\begin{array}{l}\text { Thin-bedded mud- } \\
\text { stone; thin-to- } \\
\text { medium-bedded } \\
\text { wackestone, pack- } \\
\text { stone, and thick- } \\
\text { bedded rudist bio- } \\
\text { stromes locally }\end{array}$ & $\begin{array}{l}\text { Profuse Orbitolina texana; } \\
\text { generally low relief; } \\
\text { stair-step topography not } \\
\text { well defined }\end{array}$ & $\begin{array}{l}\text { Caves related to } \\
\text { fractures and } \\
\text { bedding planes in } \\
\text { massive lime- } \\
\text { stone unit }\end{array}$ & $\begin{array}{l}\text { Both fabric and not-fabric } \\
\text { selective porosity; excellent } \\
\text { moldic, vug, fracture, and } \\
\text { cavern porosity within bio- } \\
\text { strome; very low porosity, } \\
\text { primarily fracture related, in } \\
\text { lower } 90 \text { feet }\end{array}$ \\
\hline & & & \begin{tabular}{|c|} 
Interval \\
$\mathrm{E}$
\end{tabular} & AQ & $10-20$ & $\begin{array}{l}\text { Yellow calcareous mud } \\
\text { and vuggy mudstone }\end{array}$ & $\begin{array}{l}\text { Yellow calcareous mud, } \\
\text { with springs and seeps; } \\
\text { topography tends to be } \\
\text { flat; } \text { Corbula bed at base } \\
\text { separates upper and } \\
\text { lower Glen Rose } \\
\text { Limestone }\end{array}$ & No known caves & $\begin{array}{l}\text { Fabric selective breccia poros- } \\
\text { ity; boxwork permeability } \\
\text { likely }\end{array}$ \\
\hline & $\begin{array}{l}\text { Lower } \\
\text { member }\end{array}$ & & \multirow[t]{2}{*}{ 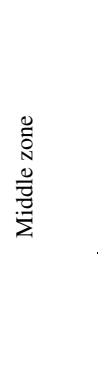 } & $\begin{array}{l}\text { AQ in bioherms } \\
\text { and evaporite } \\
\text { bed; also } \\
\text { associated } \\
\text { with karst and } \\
\text { fractures; } \\
\text { CU elsewhere }\end{array}$ & 320 & $\begin{array}{l}\text { Thick-bedded } \\
\text { mudstone; thin-to- } \\
\text { medium-bedded } \\
\text { mudstone, wacke- } \\
\text { stone, packstone, and } \\
\text { marls }\end{array}$ & $\begin{array}{l}\text { Massive mudstones; } \\
\text { massive bioherms near } \\
\text { top; below Corbula bed }\end{array}$ & $\begin{array}{l}\text { Caves in bioherms; } \\
\text { very large sink- } \\
\text { holes in bio- } \\
\text { herms; few caves } \\
\text { below bioherm } \\
\text { primarily associ- } \\
\text { ated with fracture } \\
\text { enlargement }\end{array}$ & $\begin{array}{l}\text { Both fabric and not-fabric } \\
\text { selective porosity; large } \\
\text { fracture, cavern, and moldic } \\
\text { porosity within bioherms; } \\
\text { primarily fracture porosity in } \\
\text { mudstones with little perme- } \\
\text { ability; greatest permeability } \\
\text { in bioherms. }\end{array}$ \\
\hline 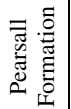 & $\begin{array}{l}\text { Bexar } \\
\text { Shale } \\
\text { member }\end{array}$ & & & $\mathrm{CU}$ & $40-70$ & $\begin{array}{l}\text { Dark mudstone, clay, } \\
\text { and shale }\end{array}$ & $*$ & $*$ & $\begin{array}{l}\text { Yields small amounts of water, } \\
\text { typically saline }\end{array}$ \\
\hline
\end{tabular}

\footnotetext{
${ }^{1}$ Referred to as "hydrostratigraphic zones" by Maclay (1995).
} 
The faults in northern Bexar County are part of the Balcones fault zone (fig. 1). The principal set of these extension faults (faults in rocks along which there has been bed-parallel elongation) generally trends southwest to northeast; a smaller set of cross faults trends southeast to northwest. Generally, the faults are en echelon (in steplike arrangement), high-angle (nearly vertical), normal (hanging wall has moved downward relative to foot wall), with the downthrown blocks typically toward the southeast.

The typical relation between the Glen Rose Limestone and the Kainer Formation shown in the outcrop map (pl. 1) results from faults that juxtapose older rocks alongside younger rocks. Not all faults are associated with topographic relief, particularly if the rocks on both sides of a fault have similar weathering characteristics and the rate of movement was similar to the rate of erosion. Additionally, some topographic differences related to faulting might be obscured where the bedrock is covered by alluvium, soils, and (or) vegetation.

\section{Stratigraphy}

The Glen Rose Limestone overlies the Pearsall Formation, which typically is a mixture of dark mudstone, clay, and shale (Barker and Ardis, 1996). The contact between the Glen Rose Limestone and Pearsall Formation typically is interfingering and gradational in Bexar County.

The Glen Rose Limestone comprises (informal) lower and upper members over most of Camp Bullis. A regionally extensive "Corbula bed" (Whitney, 1952), a concentrated accumulation of small fossil clams (Corbula martinae), marks the contact between the upper and lower members (herinafter, lower Glen Rose Limestone and upper Glen Rose Limestone). Whereas the upper Glen Rose Limestone characteristically is thin-bedded and composed mostly of soft limestones and marl, the lower Glen Rose typically is composed of relatively massive, fossiliferous limestone (Whitney, 1952). The "stair-step," terraced-hill topography that is common in much of Central Texas results largely from contrasting rates of erosion between alternating beds of relatively resistant limestone and comparatively soft marl in the upper Glen Rose Limestone.

In its area of occurrence just north of Camp Bullis, the lower Glen Rose Limestone is about 320 feet thick (Ashworth, 1983). At Camp Bullis, about 80 feet of lower Glen Rose Limestone is exposed and clearly visible along Cibolo Creek. The lowermost part of the lower Glen Rose outcrop is a dense, thick-bedded mudstone that - in some places - appears to form mounds. Above this mudstone are thick bioherms, or reeflike masses of rock composed of the calcareous remains of aquatic organisms, such as the rudistid (a bivalve). These bioherms are greater than 50 feet thick in some places. They are overlain by about 30 feet of thin-to-medium-bedded (mostly) mudstone with some wackestone and packstone. Some of the thin-bedded mudstone appears to be ripple-marked.

Stricklin and others (1971) subdivided the upper Glen Rose Limestone into eight lithologic units. From bottom to top, they described unit 1 as partly dissolved, with recrystallized limestone, dolomite, and clay; unit 2 as clay, claystone, and limestone; unit 3 as nodular limestone and clay; unit 4 as nodular limestone, calcarenite, and clay; unit 5 as a partly dissolved zone; unit 6 as clay with thin limestone beds; unit 7 as alternating beds of limestone, dolomite, and clay; and unit 8 as interbedded dolomite and dolomitic clay.

The upper Glen Rose Limestone, which appears from geophysical logs to be about 410 to 450 feet thick at Camp Bullis, has been subdivided for this report into five mappable intervals (A through E). Intervals A through $\mathrm{E}$ are described below, from oldest to youngest:

Interval E, 10 to 20 feet thick, is composed mainly of rocks containing partly to mostly dissolved evaporites; originally, this interval contained relatively soluble carbonate minerals such as gypsum and anhydrite. The Corbula bed, mostly a thin-to-very-thin-bedded grainstone, lies at the bottom of this layer and marks the base of the upper Glen Rose Limestone. Because of the more resistant characteristics of the grainstone relative to the calcareous mud above and below, the grainstone commonly is found as float (rock fragments displaced from site of origin) on the outcrop. Two Corbula beds, separated by a few feet, typically can be observed within Interval E (Hammond, 1984).

Interval $\mathrm{E}$ appears in the outcrop as a yellowish carbonate-rich mud that typically forms gentle, valleylike slopes. This interval contains numerous species of fossils, including: Orbitolina texana (Roemer), Salenia texana (Credner), Porocystis globularis (Giebel), Trigonia clavigera (Cragin), Protocardia texana (Conrad), Phymosoma texanum (Roemer), Palhemiaster comanchei (Clark), Coenholectypus sp., Tylostoma sp., Turritella sp., Artica sp., Hemiaster sp., Neithea sp., in addition to numerous species of pelecypods, gastropods, shell fragments, and worm tubes. Locally, the relatively large and typically rare 
gastropod Nerinea romeri (Whitney) can be found in abundance.

Interval D is composed of 135 to 180 feet of alternating beds of wackestone, packstone, and marl. This interval contains abundant fossils and fossil fragments. The predominant fossil is Orbitolina texana (Roemer), a foraminifera. The interval also contains Porocystis globularis (Giebel), Tapes decepta (Hill), Protocardia texana (Conrad), Turritella sp., Hemiaster sp., Neithea sp., and various species of Mollusca. Interval D contains two identifiable marker beds. The first marker bed, about 15 to 20 feet above the Corbula bed of Interval E, is a thin-bedded, silty mudstone. It can be recognized in the outcrop by its "platy" character (splits easily into very thin layers or lamina). About 90 feet of alternating wackestone, packstone, and marl lie above the mudstone marker bed. Locally, near the top of the alternating beds, is a rudist biostrome that is relatively thick bedded in places and 30 to 40 feet thick near the center of Camp Bullis; it thins to a few feet thick north of there. This rudist biostrome is composed mostly of Monopleura sp. and Toucasia sp. in the northern part of Camp Bullis and Caprinuloidea sp. in the southern part. In at least one place on the eastern side of Camp Bullis, a thick sequence of monopleurids is capped by a thick biostrome of caprinids. The caprinid biostrome is overlain by 10 to 30 feet of alternating, thin-to-mediumbedded wackestone and packstone containing abundant Orbitolina texana (Roemer) that is capped by the second marker bed, a 2- or 3-foot-thick bed of crossbedded and ripple-marked grainstone. Observed in place or as float, this grainstone is very resistant to weathering.

Interval $\mathrm{C}$ is a layer of partly to mostly dissolved carbonate minerals about 10 to 20 feet thick that originally was an evaporite bed, similar to that in Interval E at the base of the upper Glen Rose. Interval $\mathrm{C}$ has a distinctive signature, or "kick," to the left on natural gamma-ray logs. Like Interval E, it is composed of yellow-to-white calcareous mud with some very thin beds of interspersed mudstone that, together, tend to form broad, valley-like slopes. Fossils in this interval, however, are fewer in both diversity and abundance than those in Interval E. The primary fossils found in Interval $\mathrm{C}$ are Protocardia texana (Conrad), Tylostoma sp., Turritella sp., Hemiaster sp., Porocystis globularis (Giebel), and worm tubes.

Intervals B and A represent the upper 240 to 270 feet of upper Glen Rose Limestone at Camp Bullis. Both intervals are composed of alternating and interfin- gering medium-bedded mudstone to packstone, with locally occurring evaporites. The intervals are indistinguishable, however, on the basis of lithology. What distinguishes Interval B from Interval A is the generally greater density of caves in Interval A, as discussed in the next section. Fossils are rare in both intervals; the few fossils present mainly are Protocardia texana (Conrad) and Tylostoma sp. The contact is conformable between Interval A and the overlying Edwards Group.

The three members of the Kainer Formation of the Edwards Group at Camp Bullis (basal nodular, dolomitic, and Kirschberg evaporite) are composed of nodular limestone, mudstone (some places chalky), miliolid grainstone, highly altered crystalline limestone, and chert. Although the individual thickness of each member at Camp Bullis is unknown, the cumulative thickness in Bexar County ranges from about 210 to 250 feet (Stein and Ozuna, 1995, table 1).

\section{HYDROGEOLOGIC FEATURES OF THE GLEN ROSE LIMESTONE}

\section{General}

Compared to rocks of the Edwards Group, rocks of the Glen Rose Limestone generally have low porosity and little permeability. However, investigation by Veni (1994) indicates that the Glen Rose Limestone is uncharacteristically permeable in the outcrop and shallow subcrop of northern Bexar County. The results of field mapping at Camp Bullis support Veni's (1994) findings that parts of the Glen Rose Limestone exhibit greater porosity and more permeability than typically observed outside northern Bexar County.

\section{Upper Member}

\section{Interval A}

This interval, about 120 feet thick, has been referred to as the "cavernous zone" (George Veni, George Veni \& Associates, written commun., 2000) because of its relatively abundant caves. Veni (written commun., 1998) has mapped the occurrence of caves in the Glen Rose Limestone throughout south-central Texas and has graphically demonstrated a greater density of caves in this interval compared to Interval B. The cave development here is associated with well developed fracture, channel, and cavern porosity. This notfabric selective porosity has become interconnected over geologic time and thus permeable enough to now 
provide avenues for appreciable amounts of water to enter and flow through the subsurface. The contact between the Glen Rose Limestone and overlying Kainer Formation is characterized locally by cavern porosity and extremely large permeability-properties that appear to decrease with depth below land surface.

\section{Interval B}

This interval, about 120 to 150 feet thick, is similar to Interval A but with appreciably less cave development and thus less permeability overall than Interval A. The mudstones and marl that compose the major part of this interval have low not-fabric selective porosity and appear to have little, if any, permeability. This interval typically is more of a confining unit than an aquifer.

\section{Interval C}

About 10 to 20 feet thick, this interval is mostly a remnant of rocks containing relatively soluble carbonate minerals. Interval $\mathrm{C}$ is characterized by (fabric selective) breccia porosity, boxwork (intersecting blades or plates) permeability, and collapse structures associated with the dissolution of evaporites. Tending to retard the vertical percolation of ground water, this relatively thin layer diverts much of the water laterally to discharge from contact springs and seeps where the bedding intersects the land surface. Outcrops of this unit are rare and typically obscured as a result of deep weathering.

\section{Interval D}

Interval D, about 135 to 180 feet thick, is located between two intervals of partly to mostly dissolved evaporites (Intervals $\mathrm{C}$ and $\mathrm{E}$ ). Owing to an abundance of rudist biostromes and profusion of Orbitolina texana, Interval D is known among geologists as the "fossiliferous zone." Although this interval generally has low porosity and little permeability, there are local exceptions: In a few locations, some cavern porosity can be seen along fractures in the outcrop. The cross-bedded and ripple-marked grainstone marker bed at the top of Interval D has well developed (fabric selective) moldic and (not-fabric selective) vug, channel, and fracture porosity; although thin, the marker bed appears to be permeable. The caprinid biostrome just below the top of Interval D appears also to have excellent (fabric selective) moldic and (not-fabric selective) vug, fracture, and cavern porosity, which likely is sufficiently interconnected to be permeable. In addition to containing many of the stock ponds common to northern Bexar County, numerous springs discharge from the top of Interval D along contacts with overlying rocks of partly to mostly dissolved evaporites.

\section{Interval E}

As in Interval C, this relatively thin (10 to 20 feet) layer of partly to mostly dissolved evaporites-which includes the Corbula bed at its base-appears to divert the downward percolation of ground water laterally toward seeps at land surface. Many of these seeps continue to transmit water even during drought. Like Interval $\mathrm{C}$, this layer likely is characterized by boxwork permeability provided by (fabric selective) breccia porosity that resulted from collapse following the dissolution of evaporites. Although boxwork and collapse structures have not been observed at Camp Bullis (perhaps because weathering effects are obscuring such exposures), they can be observed just west of Camp Bullis.

\section{Lower Member}

At the top of the lower Glen Rose Limestone, the thin-to-medium-bedded mudstone, wackestone, and packstone appears to have low porosity and little permeability with only (not-fabric selective) fracture porosity evident and no cavern development. Field observations indicate that the largest porosity and greatest permeability in the lower Glen Rose Limestone have developed in the rudist bioherms about 30 feet below the top of this unit. The rudist zone contains well developed (fabric selective) moldic porosity and (not-fabric selective) fracture and cavern porosity. Large sinkholes and other solution structures have formed in this zone. Downward migration of water appears to be hampered by dense mudstone underlying the rudist zone; the mudstone is the lowermost exposed (along Cibolo Creek) rock of the lower Glen Rose. The only porosity evident in this mudstone appears to be fracture porosity, some of which has been solutionally enlarged. The effect of the low porosity and little permeability characteristic of this mudstone is demonstrated in the bed of Cibolo Creek where unconnected waterholes contain water even during drought.

\section{SUMMARY}

The Trinity aquifer is immediately north of and hydraulically connected to the recharge zone (outcrop) of the Edwards aquifer in Bexar County. The Glen Rose 
Limestone, which composes the upper zone and the upper part of the middle zone of the Trinity aquifer, crops out over all but the southeastern corner of the Camp Bullis Training Site; the Edwards aquifer recharge zone occupies the southeastern corner of the site. The Glen Rose Limestone, depending on its porosity and permeability, can provide avenues for recharge and (potentially) contaminants to enter the downgradient Edwards aquifer. The USGS mapped the hydrogeologic subdivisions of the Glen Rose Limestone at Camp Bullis on the basis of lithologic and hydrogeologic properties (porosity and permeability) to better understand the conditions for recharge and potential contamination.

The Glen Rose Limestone comprises a lower member and an upper member, typically composed of alternating and interfingering beds of packstone, wackestone, mudstone, and marl with interbedded grainstone and evaporites. For this report, the upper member was subdivided into five mappable intervals, A through $\mathrm{E}$ (youngest to oldest).

Intervals A and B comprise the upper 240 to 270 feet of the upper Glen Rose Limestone at Camp Bullis. Both intervals are composed of alternating and interfingering medium-bedded mudstone to packstone, with locally occurring evaporites. The intervals are distinguishable on the basis of a generally greater density of caves in Interval A. Interval B, about 120 to 150 feet thick, is similar to Interval A but with less porosity and thus less permeability overall.

Interval C, about 10 to 20 feet thick, is mostly a remnant of relatively soluble carbonate rocks characterized by breccia porosity and boxwork permeability associated with the dissolution of evaporites and collapse structures. Similar to Interval E, this layer is composed of yellow-to-white calcareous mud with some very thin beds of interspersed mudstone that together tend to form broad, valley-like slopes and retard the vertical flow of ground water.

Interval D, about 135 to 180 feet thick, is characterized by abundant fossils and fossil fragments. Although lower parts of this interval generally have low porosity and little permeability, upper parts associated with a bed of cross-bedded grainstone and a caprinid biostrome are locally porous and likely permeable. Numerous springs discharge from the top of this interval along contacts with overlying rocks of partly to mostly dissolved evaporites.

Interval E, about 10 to 20 feet thick at the base of the upper Glen Rose Limestone, crops out as a yellow- ish carbonate-rich mud that typically forms gentle, valley-like slopes. Composed mainly of rocks containing partly to mostly dissolved evaporites, this interval appears to divert the downward percolation of ground water laterally toward seeps at land surface. Interval E resembles Interval C, but Interval E contains a greater diversity and abundance of fossils.

The 80 feet of lower Glen Rose Limestone exposed at Camp Bullis appears to have low porosity and little permeability, except for a zone about 30 feet below the top of the unit that is composed largely of rudist bioherms and is relatively permeable owing to its generally well developed moldic, fracture, and cavern porosity.

\section{REFERENCES}

Arnow, Ted, 1959, Ground-water geology of Bexar County, Texas: Texas Board of Water Engineers Bulletin 5911, $62 \mathrm{p}$.

Ashworth, J.B., 1983, Ground-water availability of the Lower Cretaceous formations in the Hill Country of southcentral Texas: Texas Department of Water Resources Report 273, 173 p.

Barker, R.A., and Ardis, A.F., 1996, Hydrogeologic framework of the Edwards-Trinity aquifer system, westcentral Texas: U.S. Geological Survey Professional Paper 1421-B, $61 \mathrm{p}$.

Choquette, P.W., and Pray, L.C., 1970, Geologic nomenclature and classification of porosity in sedimentary carbonates: American Association of Petroleum Geologists Bulletin, v. 54, no. 2, p. 207-250.

Dunham, R.J., 1962, Classification of carbonate rocks according to depositional texture, in Classification of Carbonate Rocks Symposium: American Association of Petroleum Geologists Memoir 1, p. 108-121.

Forgotson, J.M., Jr., 1956, A correlation and regional stratigraphic analysis of the formations of the Trinity Group of the Comanchean Cretaceous of the Gulf Coastal Plain; and the genesis and petrology of the Ferry Creek Anhydrite: Transactions of the Gulf Coast Association of Geological Societies, v. 6, p. 91-108.

Hammond, W.W., Jr., 1984, Hydrogeology of the Lower Glen Rose aquifer, south-central Texas: Austin, University of Texas, Ph.D. dissertation, $245 \mathrm{p}$.

Maclay, R.W., 1995, Geology and hydrology of the Edwards aquifer in the San Antonio area, Texas: U.S. Geological Survey Water-Resources Investigations Report 95-4186, 64 p., 12 pl. 
Rose, P.R., 1972, Edwards Group, surface and subsurface, central Texas: Austin, University of Texas, Bureau of Economic Geology Report of Investigations 74, 198 p.

Stein, W.G., and Ozuna, G.B., 1995, Geologic framework and hydrogeologic characteristics of the Edwards aquifer recharge zone, Bexar County, Texas: U.S. Geological Survey Water-Resources Investigations Report 95-4030, 8 p.

Stricklin, F.L., Jr., Smith, C.I., and Lozo, F.E., 1971, Stratigraphy of Lower Cretaceous Trinity deposits of Central Texas: Austin, University of Texas, Bureau of Economic Geology Report of Investigations 71, 63 p.
U.S. Census Bureau, 2002, 100 largest counties, July 1, 2001: U.S. Census Bureau, Population Division, accessed August 2, 2002, at URL http://eire.census.gov/popest/data/counties/tables/ CO-EST2001-09.php

Whitney, M.I., 1952, Some zone marker fossils of the Glen Rose Formation of Central Texas: Journal of Paleontology, v. 26, no. 1, p. 65-73.

Veni, George, 1994, Geomorphology, hydrology, geochemistry, and evolution of the karstic Lower Glen Rose aquifer, south-central Texas: Pennsylvania State University, Ph.D. dissertation, $712 \mathrm{p}$. 